\title{
Chemical Constituents of Vigna luteola and Their Anti-inflammatory Bioactivity
}

\author{
Sio-Hong Lam ${ }^{1,+}{ }^{+}$, Yue-Chiun Li ${ }^{2,+}$, Ping-Chung Kuo ${ }^{1, *(\mathbb{D}}$, Tsong-Long Hwang ${ }^{3,4,5}{ }^{\mathbb{D}}$, \\ Mei-Lin Yang ${ }^{1}$, Chien-Chiao Wang ${ }^{3}$ and Jason T. C. Tzen ${ }^{2, *}$ \\ 1 School of Pharmacy, College of Medicine, National Cheng Kung University, Tainan 701, Taiwan; \\ shlam@mail.ncku.edu.tw (S.-H.L.); L3891104@nckualumni.org.tw (M.-L.Y.) \\ 2 Graduate Institute of Biotechnology, National Chung-Hsing University, Taichung 402, Taiwan; \\ ycli0126@gmail.com \\ 3 Graduate Institute of Natural Products, College of Medicine, Chang Gung University, Taoyuan 333, Taiwan; \\ htl@mail.cgu.edu.tw (T.-L.H.); D0501502@cgu.edu.tw (C.-C.W.) \\ 4 Research Center for Industry of Human Ecology, Research Center for Chinese Herbal Medicine, \\ and Graduate Institute of Health Industry Technology, Chang Gung University of Science and Technology, \\ Taoyuan 333, Taiwan \\ 5 Department of Anesthesiology, Chang Gung Memorial Hospital, Taoyuan 333, Taiwan \\ * Correspondence: z10502016@email.ncku.edu.tw (P.-C.K.); tctzen@dragon.nchu.edu.tw (J.T.C.T.); \\ Tel.: +886-6-2353535 (ext. 6806) (P.-C.K.); +886-4-22840328 (J.T.C.T.) \\ + These authors contributed equally to this work.
}

Received: 18 March 2019; Accepted: 7 April 2019; Published: 8 April 2019

check for updates

\begin{abstract}
Seventy-three compounds were identified from the methanol extract of $V$. luteola, and among these, three new (1-3) were characterized by spectroscopic and mass spectrometric analyses. The isolated constituents were assessed for anti-inflammatory potential evaluation, and several purified principles exhibited significant superoxide anion and elastase inhibitory effects.
\end{abstract}

Keywords: fabaceae; sesquiterpenoid; superoxide anion generation; elastase release

\section{Introduction}

Plenty of phytochemicals isolated from dietary and medicinal plants, such as epigallocatechin gallate [1], soy isoflavones [2], and curcumin [3,4], have been considered as promising sources of potential anticancer agents [5,6], and are one of the important sources for cancer treatment [7]. As of a thousand years ago, legumes had become essential for the protein supplements in the world. In addition, legumes are a considerable target for scientists to develop new foods, so that various seeds including the wild relatives and cultivated legumes attracted much attention. Many studies have reported that legumes possess various bioactivities [8-10]. Therefore, our team continued to explore edible wild beans as new natural health food supplements in the recent years.

Inflammation is the first response of the immune system to infection or irritation due to bacteria, virus, wound, or other various environmental factors resulting in injuring. Recently, the overexpression of neutrophils has been demonstrated to be related with various human diseases and causing serious threat to human health [11-15]. A response to diverse stimuli of the immune system is the activation of neutrophils to secrete a series of cytotoxins, such as superoxide anion and elastase [16]. Therefore, equilibrium of superoxide anion production and elastase release in infected tissues and organs is important. Furthermore, only a few available agents could directly modulate neutrophil proinflammatory responses in clinical practice. Chemoprevention is the idea of feeding natural sources to protect the human body from various diseases. Thus, utilization of anti-inflammatory health food supplements is important for the reduction of some diseases such as cancer. 
$V$. luteola (Jacq.) Benth. is a trailing or twining herb belonging to the Vigna genus usually distributed in the tropical regions. In Taiwan, $V$. luteola is grown in the open seaside at elevation below $100 \mathrm{~m}$ and spread over the island [17]. The Vigna genus has been reported to show antioxidant $[18,19]$, antifungal [20], antitumor [21,22], deworming [23,24], hypoglycemic [25,26], hepatoprotective [27,28], kidney protection [29,30], antibacterial [31,32], hypotensive [33,34], and hypolipidemic [35,36] bioactivities. In our previous research, the constituents and anti-inflammatory bioactivity of $V$. vexillata were investigated and the results exhibited potent inhibitory activity of superoxide generation and elastase release [37]. Preliminary bioassay data indicated that the methanol extract and fractions of $V$. luteola (at $10 \mu \mathrm{g} / \mathrm{mL}$ ) also displayed significant superoxide and elastase inhibition by human neutrophils in response to $\mathrm{N}$-formyl-L-methionyl-phenylalanine/cytochalasin B (fMLP/CB) (Table 1). Therefore, the present study aimed to characterize the chemical constituents and anti-inflammatory bioactivity of $V$. luteola. In total, seventy-three compounds were identified and, among these, one sesquiterpenoid (1), one alkaloid (2), and one $\alpha$-pyranone (3) were characterized based on spectroscopic and spectrometric analyses. Moreover, some of the isolated compounds were evaluated for their inhibitory activity of superoxide anion generation and elastase release.

Table 1. Inhibitory percentages of crude extract and partial purified fractions of $V$. luteola on superoxide anion generation and elastase release by human neutrophils in response to $\mathrm{N}$-formyl-L-methionyl-phenylalanine/cytochalasin B (fMLP/CB).

\begin{tabular}{ccc}
\hline \multirow{2}{*}{ Samples } & \multicolumn{2}{c}{ Inh $\%^{\mathbf{a}}$} \\
\cline { 2 - 3 } & Superoxide Anion Generation & Elastase Release \\
\hline methanol extract & $51.8 \pm 6.8^{* * *}$ & $108.4 \pm 6.9^{* * *}$ \\
chloroform fraction & $91.2 \pm 3.8^{* * *}$ & $118.0 \pm 5.0^{* * *}$ \\
water fraction & $18.3 \pm 6.1^{*}$ & $34.6 \pm 3.6^{* * *}$ \\
\hline
\end{tabular}

a Percentage of inhibition (Inh \%) at $10 \mu \mathrm{g} / \mathrm{mL}$ concentration. Results are presented as mean \pm S.E.M. $(\mathrm{n}=3) .{ }^{*} p<$ $0.05,{ }^{* * *} p<0.001$ compared with the control value (DMSO).

\section{Results and Discussion}

\subsection{Purification and Characterization}

The whole-plants of $V$. luteola were air-dried, powdered, and extracted with methanol under reflux. The methanol extract was concentrated under reduce pressure to give a deep brown syrup extract. This extract was partitioned with water and chloroform to provide two soluble layers, i.e., chloroform soluble and water soluble layers, respectively. With the assistance of a combination of conventional chromatographic techniques, one sesquiterpenoid viglutin (1), one alkaloid viglutoside (2), one $\alpha$-pyranone viglutanone (3), along with two salts sodium phaseate (4) and sodium p-coumarate (5), were characterized and their structures were constructed from the nuclear magnetic resonance (NMR) spectral elucidation and mass (MS) spectrometric analysis. Moreover, sixty-eight known compounds, including eight sesquiterpenoids, loliolide (6), isololiolide (7), blumenol A (8), kiwiionol (9), (+)-(S)-dehydrovomifoliol (10), (6S,9R)-roseoside (11), (3S,5R,6S,7E,9R)-megastigman-7-en-3,6,9-triol (12), (3S,5R,6R,7E)-3,5,6-trihydroxymegastigman-7-en-9-one (13); two sesquiterpenoids, abscisic acid (14) and machilusoxide A (15); one diterpenoid, 3(17)-phytene-1,2-diol (16); two triterpenoids, lupeol (17) and simiarenol (18); seven steroids, mixture of $\beta$-sitosterol (19) and stigmasterol (20), mixture of $\beta$-sitosteryl-3-O- $\beta$-D-glucoside (21), and stigmasteryl-3-O- $\beta$-D-glucoside (22), mixture of stigmast-4-en-3-one (23) and stigmast-4,22-dien-3-one (24), ergosterol peroxide (25); one lignan, (+)-pinoresinol (26); eight alkaloids, uracil (27), uridine (28), 6-hydroxymethyl-3-pyridinol (29), thymine (30), adenine (31), nicotinamide (32), potassium nicotinate (33), 6-hydroxynicotinic acid (34); nineteen benzenoids, $p$-hydroxybenzoic acid (35), methylparaben (36), trans-methyl $p$-coumarate (37), (E)-methyl ferulate (38), trans-isoferulic acid (39), trans-ferulic acid (40), isovanillic acid (41), methyl vanillate (42), vanillic acid (43), 4-hydroxybenzaldehyde (44), syringic acid (45), gentisic acid (46), 
sodium salicylate (47), benzoic acid (48), methyl 2-O- $\beta$-D-glucopyranosylsalicylate (49), protocatechuic acid (50), phenylacetic acid (51), benzyl alcohol $\beta$-D-glucopyranosyl $(1 \rightarrow 6)-\beta$-D-glucopyranoside (52), gentisic acid 5-O- $\beta$-D-xylopyranoside (53); nine flavonoids, kaempferol (54), liquiritigenin (55), kaempferol 3-O-[ $\alpha$-L-rhamnopyranosyl $(1 \rightarrow 6)]-\beta$-D-galactopyranoside (56), chrysoeriol (57), astragalin (58), kaempferol-3-O-sophoroside (59), kaempferol 3-O-sophoroside-7-O-rhamnoside (60), robinin (61), isorhamnetin 3-O-[ $\alpha$-L-rhamnopyranosyl $(1 \rightarrow 6)]-\beta$-D-galactopyranoside $7-O-\alpha$-L-rhamnopyranoside (62); eight isoflavonoids, daidzein (63), 8-O-methylretusin (64), 5,7,4'-trihydroxyisoflavone (65), 7,2', $4^{\prime}$-trihydroxyisoflavone (66), tectorigenin (67), afromosin (68), $3^{\prime}$-methoxydaidzein (69), 7,4'-dihydroxy-8-methoxyisoflavone (70); three others, 2-furanoic acid (71), maltol glucoside (72), sodium 5-hydroxymethylfuran-2-carboxylate (73), respectively, were verified by inspection of their reported spectroscopic data (references of known compounds were provided in Supplementary Materials).

\subsection{Structural Elucidations of 1-5}

Compound $\mathbf{1}$ was isolated as optically active yellow powder, and the molecular formula was assigned as $\mathrm{C}_{13} \mathrm{H}_{22} \mathrm{O}_{3}$ with a sodium adduct ion peak at $m / z 249.1460$ in high-resolution electrospray ionization mass spectrometry (HR-ESI-MS) analysis. The infrared (IR) absorption bands at 3416 and $1647 \mathrm{~cm}^{-1}$ were in agreement with the presences of hydroxy and carbon-carbon double bond functionalities, respectively. In the ${ }^{1} \mathrm{H}-\mathrm{NMR}$ spectrum, there were proton signals for two methyl singlets at $\delta 0.96\left(3 \mathrm{H}, \mathrm{s}, \mathrm{CH}_{3}-11\right), 1.06\left(3 \mathrm{H}, \mathrm{s}, \mathrm{CH}_{3}-12\right)$, one methyl doublet of doublets $1.73(3 \mathrm{H}, \mathrm{dd}, J=$ $\left.6.5,1.5 \mathrm{~Hz}, \mathrm{CH}_{3}-10\right)$, two oxymethylene protons at $\delta 3.61(1 \mathrm{H}, \mathrm{dd}, J=11.0,7.0 \mathrm{~Hz}, \mathrm{H}-13 \mathrm{a})$ and $3.81(1 \mathrm{H}$, $\mathrm{m}, \mathrm{H}-13 \mathrm{~b})$, two oxymethine at $\delta 3.80(1 \mathrm{H}, \mathrm{dddd}, J=12.0,7.5,5.0,3.5 \mathrm{~Hz}, \mathrm{H}-3)$ and $4.18(1 \mathrm{H}, \mathrm{d}, J=8.5$ $\mathrm{Hz}, \mathrm{H}-7)$, three methines at $\delta 1.36(1 \mathrm{H}, \mathrm{ddd}, J=12.6,5.0,1.5 \mathrm{~Hz}, \mathrm{H}-2 \mathrm{~b}), 1.51(1 \mathrm{H}$, ddd, $J=12.0,12.0$, $11.5 \mathrm{~Hz}, \mathrm{H}-4 \mathrm{a}), 2.44(1 \mathrm{H}, \mathrm{m}, \mathrm{H}-5)$, and two trans olefinic protons at $\delta 5.67(1 \mathrm{H}, \mathrm{ddd}, J=15.5,8.5,1.5$ $\mathrm{Hz}, \mathrm{H}-8)$ and $5.78(1 \mathrm{H}, \mathrm{dq}, J=15.5,6.5 \mathrm{~Hz}, \mathrm{H}-9)$. The ${ }^{13} \mathrm{C}-\mathrm{NMR}$ and distortionless enhancement by polarization transfer (DEPT) spectra exhibited three methyl carbons at $\delta 18.2$ (C-10), 24.0 (C-12) and 25.9 (C-11); three methylene carbons at $\delta 31.6$ (C-4), 46.8 (C-2), and 69.7 (C-13); five methines at $\delta 43.7$ (C-5), 68.5 (C-3), 84.4 (C-7), 129.6 (C-8), and 132.1 (C-9); and two quaternary carbons at $\delta 37.7$ (C-1) and 81.2 (C-6). The correlation spectroscopy (COSY) indicated the linkage of $\mathrm{H}-2 / \mathrm{H}-3 / \mathrm{H}-4 / \mathrm{H}-5 / \mathrm{H}-13$ and $\mathrm{H}-7 / \mathrm{H}-8 / \mathrm{H}-9 / \mathrm{H}-10$ (Figure 1 ). The ${ }^{2} \mathrm{~J}$ - and ${ }^{3} \mathrm{~J}$ - correlation peaks from $\mathrm{H}-2$ to $\mathrm{C}-4$ and $\mathrm{C}-6$; from H-3 to C-5; from H-7 to C-8 and C-9; from H-8 to C-10; from H-13 to C-6 and C-7; and from $\mathrm{CH}_{3}-11$ to $\mathrm{C}-1, \mathrm{C}-2, \mathrm{C}-6$, and $\mathrm{CH}_{3}-12$, respectively, were observed in the 2-dimensions (2D) heteronuclear multiple bond correlation (HMBC) spectrum (Figure 1). In addition, the index of hydrogen deficiency $(\mathrm{IHD}=3$ ) of $\mathbf{1}$ suggested the presences of one double bond and two rings in $\mathbf{1}$. According to this spectral evidence, the planar structure of $\mathbf{1}$ was constructed as shown (Figure 1). Furthermore, the large coupling constant of $\mathrm{H}-3(12.0 \mathrm{~Hz})$ revealed its axial orientation, and the correlations of $\mathrm{H}-3 / \mathrm{H}-5$, $\mathrm{H}-5 / \mathrm{H}-13$, and $\mathrm{CH}_{3}-12 / \mathrm{H}-7$ in the Nuclear Overhauser Effect spectroscopy (NOESY) established its relative stereochemistry configuration (Figure 1). All the proton and carbon signals assignments were achieved by the combination of 2D NMR experiments (see Supplementary Materials). Conclusively, the structure of $\mathbf{1}$ was assigned as shown based on the experimental results which mentioned above and named trivially as viglutin. 

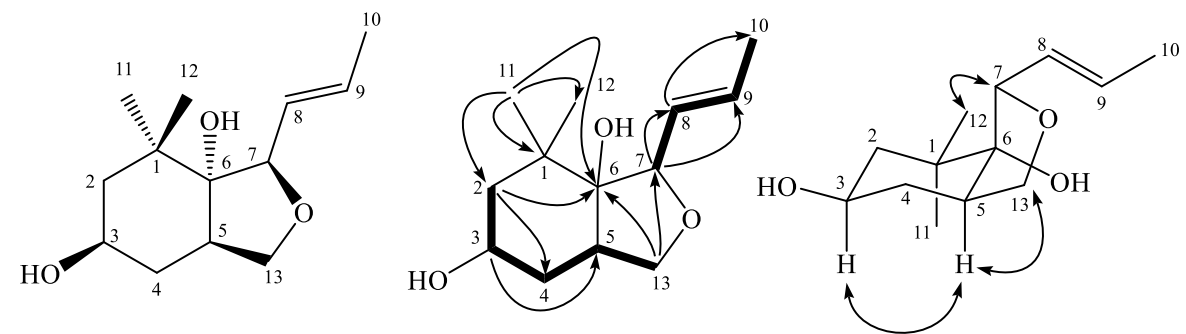

1

Figure 1. Key COSY $(\boldsymbol{\bullet}), \operatorname{HMBC}(\rightarrow)$, and NOESY $(\leftrightarrow)$ correlations of $\mathbf{1}$.

Compound 2 was assigned a molecular formula of $\mathrm{C}_{12} \mathrm{H}_{17} \mathrm{NO}_{6}$ from its HR-ESI-MS analytical data $\left(\mathrm{m} / \mathrm{z} 294.0952\right.$, calc. for $\left.\mathrm{C}_{12} \mathrm{H}_{17} \mathrm{NNaO}_{6}, 294.0954\right)$. The UV absorption maxima at 274 and 221 $\mathrm{nm}$ were indication of the heteroaromatic chromophore [38], and it was further supported by the downfield ABX-coupled aromatic protons at $\delta 7.21(1 \mathrm{H}, \mathrm{dd}, J=8.5,2.5 \mathrm{~Hz}, \mathrm{H}-4), 7.32(1 \mathrm{H}, \mathrm{d}, J=8.5$ $\mathrm{Hz}, \mathrm{H}-5)$, and $8.03(1 \mathrm{H}, \mathrm{d}, J=2.5 \mathrm{~Hz}, \mathrm{H}-2)$. The existence of hydroxyl and carbon-carbon double bond functionalities could be determined from the IR absorption bands at 3430 and $1637 \mathrm{~cm}^{-1}$. One methylene group at $\delta 4.51(1 \mathrm{H}, \mathrm{d}, J=12.0 \mathrm{~Hz}, \mathrm{H}-7 \mathrm{a})$ and $4.65(1 \mathrm{H}, \mathrm{d}, J=12.0 \mathrm{~Hz}, \mathrm{H}-7 \mathrm{~b})$, and one set of rhamnose protons at $\delta 1.25\left(3 \mathrm{H}, \mathrm{d}, J=6.0 \mathrm{~Hz}, \mathrm{H}-6^{\prime}\right), 3.38\left(1 \mathrm{H}, \mathrm{dd}, J=9.5,9.5 \mathrm{~Hz}, \mathrm{H}-4^{\prime}\right), 3.60(1 \mathrm{H}, \mathrm{dd}$, $\left.J=9.5,6.0 \mathrm{~Hz}, \mathrm{H}-5^{\prime}\right), 3.67\left(1 \mathrm{H}, \mathrm{dd}, J=9.5,3.5 \mathrm{~Hz}, \mathrm{H}-3^{\prime}\right), 3.85\left(1 \mathrm{H}, \mathrm{dd}, J=3.5,2.0 \mathrm{~Hz}, \mathrm{H}-2^{\prime}\right)$, and 4.78 $\left(1 \mathrm{H}, \mathrm{d}, J=2.0 \mathrm{~Hz}, \mathrm{H}-1^{\prime}\right)$ appeared in the ${ }^{1} \mathrm{H}-\mathrm{NMR}$ spectrum of 2 . In its ${ }^{13} \mathrm{C}-\mathrm{NMR}$ spectrum, a set of signals at $\delta 18.0\left(\mathrm{C}-6^{\prime}\right), 70.1\left(\mathrm{C}-5^{\prime}\right), 72.3\left(\mathrm{C}-2^{\prime}\right), 72.4\left(\mathrm{C}-3^{\prime}\right), 74.0\left(\mathrm{C}-4^{\prime}\right)$, and $101.4\left(\mathrm{C}-1^{\prime}\right)$ also evidenced the presence of rhamnoside [39]. The observed HMBC correlations from $\mathrm{H}-2$ to $\mathrm{C}-3, \mathrm{C}-4$, and C-6; from $\mathrm{H}-4$ to $\mathrm{C}-6$; from $\mathrm{H}-5$ to $\mathrm{C}-3$ and $\mathrm{C}-6$; from $\mathrm{H}-7$ to $\mathrm{C}-5, \mathrm{C}-6$, and $\mathrm{C}-\mathrm{1}^{\prime}$; from $\mathrm{H}-\mathbf{1}^{\prime}$ to $\mathrm{C}-3^{\prime}$ and $\mathrm{C}-5^{\prime}$, respectively, established the structure of 2 as $6-(\alpha$-rhamnosyloxymethyl)-3-pyridinol (Figure 2$)$ and assigned the trivial name as viglutoside.

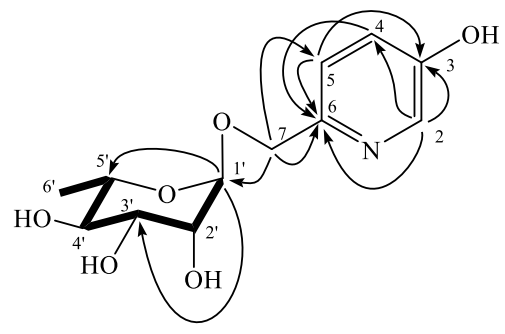

2

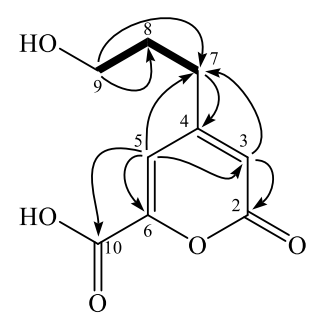

3

Figure 2. Key $\operatorname{COSY}(\boldsymbol{\square})$ and $\operatorname{HMBC}(\rightarrow)$ correlations of 2 and $\mathbf{3}$.

Viglutanone (3) was isolated as brown syrup, and the molecular formula was determined as $\mathrm{C}_{9} \mathrm{H}_{10} \mathrm{O}_{5}$ by a deprotonated molecular ion peak at $m / z$ 197.0449 in the HR-ESI-MS analysis. The UV absorption maximum at $299 \mathrm{~nm}$ and IR absorption bands at 3493,1703, and $1631 \mathrm{~cm}^{-1}$, along with the consideration of IHD value (5) proposed the presence of an $\alpha$-pyranone basic structure with a carboxylic acid group. It was further evidenced by the proton signals for two vinyl singlets at $\delta 6.25$ $(1 \mathrm{H}, \mathrm{H}-3)$ and $6.97(1 \mathrm{H}, \mathrm{H}-5)$ in ${ }^{1} \mathrm{H}-\mathrm{NMR}$, and the carbon peaks for two vinyl groups at $\delta 110.4(\mathrm{C}-5)$, 114.8 (C-3), 156.4 (C-6), and 162.3 (C-4), and two carbonyls at $\delta 164.8$ (C-2) and 165.8 (C-10), respectively. In addition, three methylene groups responsible for the propyloxyl substituent at $\delta 1.84(2 \mathrm{H}, \mathrm{tt}, J=$ 8.0, $6.4 \mathrm{~Hz}, \mathrm{H}-8), 2.60(2 \mathrm{H}, \mathrm{t}, J=8.0 \mathrm{~Hz}, \mathrm{H}-7)$, and $3.60(2 \mathrm{H}, \mathrm{t}, J=6.4 \mathrm{~Hz}, \mathrm{H}-9)$ were observed in the ${ }^{1} \mathrm{H}-\mathrm{NMR}$ spectrum of 3 . The ${ }^{2} \mathrm{~J}$ - and ${ }^{3} \mathrm{~J}$-HMBC correlations from $\mathrm{H}-3$ to C-2 and C-7; from $\mathrm{H}-5$ to C-3, C-6, C-7, and C-10; from H-7 to C-4; and from H-9 to C-7 and C-8 concluded the structure of 3 as the $\alpha$-pyranone basic skeleton substituted with a propyloxyl fragment at $\mathrm{C}-4$ and a carboxyl group at C-6 as shown (Figure 2). 
In addition to new compounds 1-3, two sodium salts 4 and 5 were also characterized from the methanol extract of $V$. luteola. Compound 4 was obtained as optically active white powder, and exhibited a protonated molecular at $m / z 279.1234$ in the HR-ESI-MS experiment. The ultraviolet (UV) absorption maxima at $249 \mathrm{~nm}$ and the IR absorption bands at 3424, 1713, and $1644 \mathrm{~cm}^{-1}$ suggested the occurrences of hydroxyl, carbonyl, and conjugated carbonyl groups in the molecule. The ${ }^{1} \mathrm{H}-\mathrm{NMR}$ spectrum of 4 exhibited signals for two trans olefinic protons at $\delta 6.20(1 \mathrm{H}, \mathrm{d}, J=16.0 \mathrm{~Hz}, \mathrm{H}-7)$ and $7.87(1 \mathrm{H}, \mathrm{d}, J=16.0 \mathrm{~Hz}, \mathrm{H}-8)$; one vinyl proton at $\delta 5.86(1 \mathrm{H}$, br s, $\mathrm{H}-10)$; three methyl singlets at $\delta 1.00$ $\left(3 \mathrm{H}, \mathrm{CH}_{3}-13\right), 1.22\left(3 \mathrm{H}, \mathrm{CH}_{3}-14\right)$, and $1.95\left(3 \mathrm{H}, \mathrm{CH}_{3}-15\right)$; and three methylene groups at $\delta 2.37(1 \mathrm{H}$, $\mathrm{dd}, J=18.0,2.4 \mathrm{~Hz}, \mathrm{H}-2 \mathrm{a}), 2.45(1 \mathrm{H}, \mathrm{dd}, J=18.0,2.4 \mathrm{~Hz}, \mathrm{H}-4 \mathrm{a}), 2.71(1 \mathrm{H}, \mathrm{dd}, J=18.0,2.4 \mathrm{~Hz}, \mathrm{H}-2 \mathrm{~b})$, $2.81(1 \mathrm{H}, \mathrm{d}, J=18.0 \mathrm{~Hz}, \mathrm{H}-4 \mathrm{~b}), 3.65(1 \mathrm{H}, \mathrm{d}, J=7.2 \mathrm{~Hz}, \mathrm{H}-12 \mathrm{a})$, and $3.93(1 \mathrm{H}, \mathrm{dd}, J=7.2,2.8 \mathrm{~Hz}, \mathrm{H}-12 \mathrm{~b})$. The ${ }^{13} \mathrm{C}$-NMR spectrum also displayed one carbonyl carbon at $\delta 211.3$ (C-3); one carboxyl signal at $\delta$ 175.0 (C-11); three methyl carbons at $\delta 15.8$ (C-13), 19.4 (C-14), and 20.5 (C-15); three methylene carbons at $\delta 53.2(\mathrm{C}-2), 54.0(\mathrm{C}-4)$, and 78.5 (C-12); three methines at $\delta 127.9(\mathrm{C}-10), 129.2(\mathrm{C}-7)$, and 134.1 (C-8); and four quaternary carbons at $\delta 49.0$ (C-1), 82.8 (C-6), 87.8 (C-5), and 141.6 (C-9), respectively. The ${ }^{2} \mathrm{~J}$ - and ${ }^{3} \mathrm{~J}-\mathrm{HMBC}$ correlations from $\mathrm{H}-2$ to $\mathrm{C}-3, \mathrm{C}-6$; from $\mathrm{H}-7$ to C-6, C-8, and C-9; from H-8 to $\mathrm{C}-10$, and $\mathrm{CH}_{3}-15$; from $\mathrm{H}-10$ to $\mathrm{C}-11$ and $\mathrm{CH}_{3}-15$; from $\mathrm{H}-12$ to $\mathrm{C}-1, \mathrm{C}-2, \mathrm{C}-6$, and $\mathrm{CH}_{3}-13$; and from $\mathrm{CH}_{3}-14$ to $\mathrm{C}-4$ and $\mathrm{C}-6$, respectively, provided the possible planar structure as shown (Figure 3). Compared the spectral data of 4 with those of (-)-phaseic acid [40], the upfield shift of H-5 ( $\delta 8.11$ to 7.87) and ${ }^{13} \mathrm{C}$ NMR signal of the carboxylate at $\delta 175.0(\mathrm{C}-11)$ further indicated the occurrence of sodium carboxylate. The presence of 4 as a sodium salt was evidenced by the inductively coupled plasma (ICP) MS analytical data, in which $\left[\mathrm{Na}^{+}\right]$was equal to $0.8 \mathrm{ppm}$ in the $10 \mathrm{ppm}$ sample. After acidification of 4 with $0.1 \mathrm{M} \mathrm{HCl}$, the spectral data was changed to be the same as that of $(-)$-phaseic acid [40]. Furthermore, the NOE correlations of $\mathrm{H}-7$ and $\mathrm{CH}_{3}-13, \mathrm{H}-7$ and $\mathrm{CH}_{3}-15$, and $\mathrm{H}-10$ and $\mathrm{CH}_{3}-15$, confirmed the relative stereochemical structure of 4 as sodium phaseate (Figure 3).

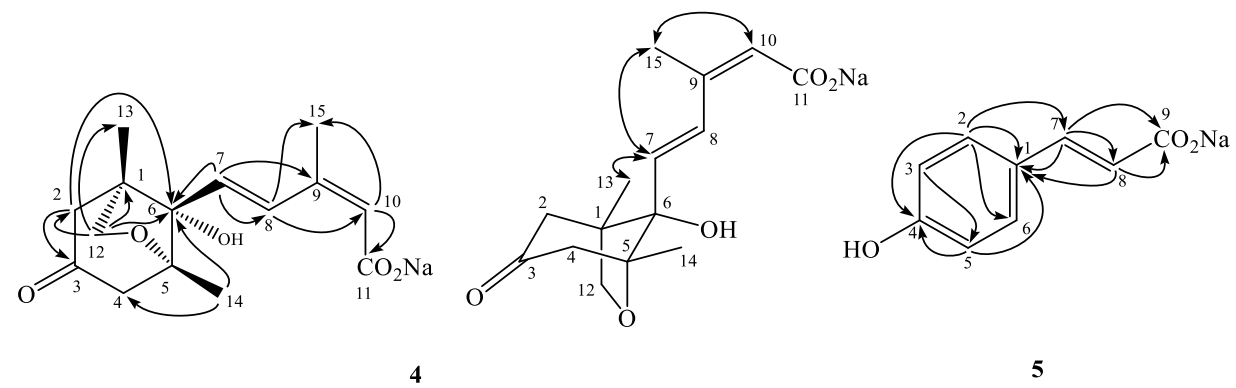

Figure 3. Key $\operatorname{HMBC}(\rightarrow)$ and NOESY $(\leftrightarrow)$ correlations of 4 and 5 .

Compound 5 was purified as colorless powder and its molecular formula was characterized as $\mathrm{C}_{9} \mathrm{H}_{7} \mathrm{O}_{3}$ according to the HR-ESI-MS data. The UV absorption maxima at $282 \mathrm{~nm}$ and the IR absorption bands at 3403 and $1550 \mathrm{~cm}^{-1}$ suggested the occurrence of hydroxyl and carboxyl groups in the molecule. Only $\mathrm{A}_{2} \mathrm{~B}_{2}$-coupled aromatic protons at $\delta 6.75(2 \mathrm{H}, \mathrm{d}, J=8.8 \mathrm{~Hz}, \mathrm{H}-3,5)$ and 7.36 $(2 \mathrm{H}, \mathrm{d}, J=8.8 \mathrm{~Hz}, \mathrm{H}-2,6)$, and two trans olefinic protons at $\delta 6.33(1 \mathrm{H}, \mathrm{d}, J=15.6 \mathrm{~Hz}, \mathrm{H}-8)$ and 7.33 $(1 \mathrm{H}, \mathrm{d}, J=15.6 \mathrm{~Hz}, \mathrm{H}-7)$ could be observed in its ${ }^{1} \mathrm{H}-\mathrm{NMR}$ spectrum. Compared the spectral data of 5 with those of $p$-coumaric acid [41], the upfield shift of H-7 ( $\delta 7.60$ to 7.33) and ${ }^{13} \mathrm{C}$ NMR signal of the carboxylate at $\delta 176.4$ (C-9) further indicated the occurrence of sodium carboxylate in 5 . The ${ }^{2} \mathrm{~J}$ and ${ }^{3} \mathrm{~J}-\mathrm{HMBC}$ correlations from $\mathrm{H}-2$ to C-1, C-4, C-6, and C-7; from H-3 to C-5; from H-5 to C-1 and C-4; from H-7 to C-1, C-8, and C-9; and from H-8 to C-1 and C-9, respectively, evidenced the planar structure of 5 (Figure 3). The presence of 5 as a sodium salt was evidenced by the ICPMS analytical data, in which $\left[\mathrm{Na}^{+}\right]$was equal to $2 \mathrm{ppm}$ in the $10 \mathrm{ppm}$ sample. After acidification of 5 with $0.1 \mathrm{M} \mathrm{HCl}$, the spectral data was changed to be the same as that of $p$-coumaric acid [41]. These data determined the structure of 5 as sodium $p$-coumarate. Although compound 5 was already reported in 2012 [42], the present research is the first report of 5 from the natural sources. 


\subsection{Anti-Inflammatory Activity}

Most of the purified compounds were examined for their inhibitory activity against the superoxide anion and elastase release by human neutrophils in response to fMLP/CB [43] (Table S1), and only those compounds with $\mathrm{IC}_{50}$ values lower than $10 \mu \mathrm{M}$ are listed in Table 2. The experimental data indicated $\mathbf{2 6}, 54,55,57,63,65,67$, and 70 displayed significant inhibition of superoxide anion generation with $\mathrm{IC}_{50}$ values ranged from $1.9 \pm 0.2$ to $9.3 \pm 0.3 \mu \mathrm{M}$, as compared with the positive control LY294002 $\left(\mathrm{IC}_{50} 1.0 \pm 0.2 \mu \mathrm{M}\right)$. In addition, 55, 57, 63, 65, 66, and 67 exhibited significant inhibition of elastase release with $\mathrm{IC}_{50}$ values ranged from $3.8 \pm 0.1$ to $7.7 \pm 0.5 \mu \mathrm{M}$, as compared with the positive control LY294002 ( $\mathrm{IC}_{50} 3.1 \pm 0.7 \mu \mathrm{M}$ ). These experimental results indicated that flavonoids and isoflavonoids in Vigna species displayed significant chemoprevention potentials. According to the anti-inflammatory activity examinations performed in this study, the crude extract and purified constituents of V. luteola could be developed as new lead compounds or health food ingredients in the future.

Table 2. Inhibitory effects of purified compounds on superoxide anion generation and elastase release by human neutrophils in response to fMLP/CB.

\begin{tabular}{|c|c|c|c|c|}
\hline \multirow{2}{*}{ Compound } & \multicolumn{2}{|c|}{ Superoxide Anion Generation } & \multicolumn{2}{|c|}{ Elastase Release } \\
\hline & $\mathrm{IC}_{50}(\mu \mathrm{M})^{\mathrm{a}}$ & $\operatorname{Inh} \% \mathrm{~b}$ & $\mathrm{IC}_{50}(\mu \mathrm{M})$ & Inh \% \\
\hline 26 & $6.1 \pm 0.3$ & $69.9 \pm 4.4^{* * *}$ & $-{ }^{c}$ & $11.8 \pm 2.1^{* *}$ \\
\hline 54 & $4.5 \pm 0.3$ & $93.6 \pm 3.3^{* * *}$ & - & $23.7 \pm 1.1^{* * *}$ \\
\hline 55 & $4.1 \pm 0.2$ & $99.0 \pm 1.9^{* * *}$ & $3.8 \pm 0.1$ & $89.4 \pm 4.5^{\text {*** }}$ \\
\hline 57 & $5.0 \pm 0.4$ & $88.4 \pm 5.3^{* * *}$ & $4.7 \pm 0.4$ & $89.9 \pm 2.2^{* * *}$ \\
\hline 63 & $9.3 \pm 0.3$ & $52.5 \pm 1.2^{* * *}$ & $4.9 \pm 0.2$ & $75.2 \pm 3.2$ *** \\
\hline 65 & $1.9 \pm 0.2$ & $89.3 \pm 2.9^{* * *}$ & $6.4 \pm 0.7$ & $61.3 \pm 4.7^{* * * *}$ \\
\hline 66 & - & $27.4 \pm 7.5 *$ & $7.7 \pm 0.5$ & $60.4 \pm 2.3^{* * * *}$ \\
\hline 67 & $3.2 \pm 0.1$ & $100.0 \pm 1.3^{* * *}$ & $4.1 \pm 0.7$ & $99.6 \pm 7.6$ **** \\
\hline 70 & $5.6 \pm 0.9$ & $85.2 \pm 9.7^{* * *}$ & - & $46.5 \pm 2.2^{* * *}$ \\
\hline LY294002 d & $1.0 \pm 0.2$ & & $3.1 \pm 0.7$ & \\
\hline
\end{tabular}

Results are presented as mean $\pm \operatorname{SEM}(\mathrm{n}=3) .{ }^{*} p<0.05,{ }^{* *} p<0.01,{ }^{* * *} p<0.001$ compared with the control (DMSO).

${ }^{a}$ Concentration necessary for $50 \%$ inhibition $\left(\mathrm{IC}_{50}\right) .{ }^{\mathrm{b}}$ Percentage of inhibition (Inh \%) at $10 \mu \mathrm{M}$ concentration. ${ }^{\mathrm{c}}$

Not determined. ${ }^{\mathrm{d}}$ A phosphatidylinositol-3-kinase inhibitor was used as a positive control.

\section{Experimental Section}

\subsection{General}

The spectroscopic data of the purified compounds including optical rotations $\left([\alpha]_{\mathrm{D}}{ }^{25}\right)$ and UV and IR spectra were recorded on a Jasco P-2000 digital polarimeter (Jasco, Tokyo, Japan), a Hitachi U-0080D diode array spectrophotometer (Hitachi, Tokyo, Japan), and a Jasco FT/IR-4100 spectrophotometer (Jasco, Tokyo, Japan), respectively. The mass spectra were collected on a Shimadzu LC-MS 8040 spectrometer (Shimadzu, Kyoto, Japan). The HRMS data were obtained on a JMS-T100LP spectrometer (Jeol, Tokyo, Japan). ICPMS examination was performed on a Thermo-Element XR ICPMS spectrometer, and three elements $(\mathrm{Na}, \mathrm{K}$, and $\mathrm{Ca}$ ) were examined for their concentration by comparison with the standard curves. ${ }^{1} \mathrm{H}-,{ }^{13} \mathrm{C}-$, and $2 \mathrm{D}$ NMR spectra were recorded on the Bruker AV-500 and Avance III-400 NMR spectrometers (Bruker, Billerica, MA, USA) using tetramethylsilane as the internal standard, and all NMR experiments were detected on standard pulse sequences and parameters with all chemical shifts reported in parts per million (ppm, $\delta$ ). The deuterated solvents were purchased from Sigma-Aldrich (St. Louis, MO, USA). Other chemicals used in this study were provided by Merck KGaA (Darmstadt, Germany). Column chromatography was performed on silica gels in different mesh sizes (70-230 and 230-400 mesh, Kieselgel 60, Merck KGaA, Darmstadt, Germany). Thin-layer chromatography (TLC) was conducted on precoated Kieselgel 60 F 254 plates (Merck KGaA, Darmstadt, Germany). The spots on TLC were detected by UV light or spraying with $10 \%(v / v) \mathrm{H}_{2} \mathrm{SO}_{4}$ followed by heating at $110^{\circ} \mathrm{C}$ for $10 \mathrm{~min}$. 


\subsection{Plant Materials}

The plant material Vigna luteola (Jacq.) Benth. was gathered in the side of Ching-Shui River, Nantou, Taiwan (March 2006), and it was authenticated by Prof. C. S. Kuoh (Department of Life Science, National Cheng Kung University, Tainan, Taiwan). A voucher specimen (PCKuo_2006002) was deposited in the herbarium of School of Pharmacy, National Cheng Kung University, Tainan, Taiwan.

\subsection{Extraction and Isolation}

The herbs of $V$. luteola (dried weight: $3.5 \mathrm{~kg}$ ) were grounded and extracted with methanol $(20 \mathrm{~L})$ exhaustively under reflux $\left(85^{\circ} \mathrm{C}\right)$ for 8 hours, and the resulting liquid was concentrated in vacuo to give a dark brown syrup ( $640 \mathrm{~g})$. The methanol extract was partitioned between chloroform and water to produce chloroform soluble layer $(190 \mathrm{~g})$ and water soluble layer (450 g), respectively.

The chloroform layer was subjected to a silica gel column eluted with a step gradient of $n$-hexane and acetone (100:1 to 1:1) to afford seven fractions (CF 1-7), as monitored by TLC. CF 3 was further column chromatographed on silica gel with a mixture of $n$-hexane and ethyl acetate (step gradient from 50:1 to 1:1) to afford fourteen subfractions (CF 3-1-3-14). CF 3-2 was purified by silica gel column chromatography $\left(\mathrm{SiO}_{2} \mathrm{CC}\right)$ and the minor fraction was recrystallized from chloroform to give 18 (0.3 g). CF 3-3 was isolated by $\mathrm{SiO}_{2} \mathrm{CC}$ to yield $16(0.8 \mathrm{mg}), 17(1.1 \mathrm{mg}), \mathbf{4 0}(1.8 \mathrm{mg})$, a mixture of 19 and $20(2.5 \mathrm{mg})$, and a mixture of 23 and $24(2.2 \mathrm{mg})$, respectively. CF 3-5 was separated by $\mathrm{SiO}_{2} \mathrm{CC}$ and further preparative thin-layer chromatography (pTLC) purification afforded compounds 6 (1.6 mg), 7 (4.3 mg), 37 (4.2 mg), 69 (0.6 mg), 8 (5.4 mg), 14 (1.2 mg), 55 (1.8 mg), and 63 (2.0 mg), respectively. CF 6 was further subjected on a silica gel column and eluted with a chloroform and methanol mixture (step gradient from 50:1 to 1:1) to produce thirteen subfractions (CF 6-1-6-13). A mixture of 21 and 22 $(4.3 \mathrm{mg})$ was obtained from CF 6-7 by recrystallization of ethyl acetate. CF 6-8 was purified by $\mathrm{SiO}_{2} \mathrm{CC}$ and the minor fraction was further isolated by pTLC with a solvent mixture of chloroform and acetone (10:1) to obtain 41 (1.0 mg). CF 7 was isolated on a $\mathrm{SiO}_{2} \mathrm{CC}$ eluted with chloroform and methanol (step gradient from 50:1 to 1:1) to give twelve subfractions (CF 7-1-7-12). CF 7-3, 7-4, 7-5, and 7-8 were purified by $\mathrm{SiO}_{2} \mathrm{CC}$ and the resulting minor fractions were subjected to pTLC to yield $68(2.3 \mathrm{mg}), 25$ (1.9 mg) and $64(1.5 \mathrm{mg}), 10(1.6 \mathrm{mg})$ and $43(5.1 \mathrm{mg})$, and 36 (2.2 $\mathrm{mg})$, respectively.

The water soluble layer was resolved on a Diaion HP-20 column and eluted with a step gradient mixture of water and methanol (10:0, 7:3, 5:5, 3:7, and 0:10) to result in sixteen fractions (WF 1-16). WF 1 was subjected to Diaion HP-20 CC eluted with the same program as mentioned above to obtain nine subfractions (WF 1-1-1-9). WF 1-3 was purified by pTLC with a solvent mixture of chloroform and methanol (50:1) to give 26 (3.1 mg) and $38(1.5 \mathrm{mg})$. WF 1-4 was separated by $\mathrm{SiO}_{2} \mathrm{CC}$ and further purified by pTLC to afford $65(2.2 \mathrm{mg}), 67(6.0 \mathrm{mg}), 35(24.0 \mathrm{mg})$, and $54(2.7 \mathrm{mg})$. WF 3 was purified by Sephadex LH-20 CC eluted with a step gradient mixture of water and methanol (10:0, 7:3, 5:5, 3:7, and 0:10) to produce thirteen subfractions (WF 3-1-3-13). WF 3-4 and 3-9 were separated by pTLC to yield $70(1.3 \mathrm{mg}), 48(2.4 \mathrm{mg})$, and $56(7.3 \mathrm{mg})$. WF 3-10 was purified by $\mathrm{SiO}_{2} \mathrm{CC}$ eluted with a step gradient mixture of chloroform and methanol (50:1 to 1:1) to produce eight minor fractions (WF 3-10-1-3-10-8). WF 3-10-2 was isolated by reversed-phase HPLC with a Gemini 5u C18 column (250 $\times 4.6 \mathrm{~mm}, 5 \mu \mathrm{m})$ eluted with a $\mathrm{MeOH}-\mathrm{H}_{2} \mathrm{O}$ mixture $(40: 60,0.4 \mathrm{~mL} / \mathrm{min})$ to yield $61(2.7 \mathrm{mg})$ and 62 (3.5 mg). WF 5 was isolated by Diaion HP-20 CC to give six subfractions (WF 5-1 5-6). WF 5-4 was subjected on a Sephadex LH-20 column eluted with a mixture of water and methanol (10:0, 7:3, $5: 5,3: 7$, and $0: 10)$, and then recrystallization of the resulting minor fractions afforded $66(2.2 \mathrm{mg}), 71$ (1.1 mg), 4 (3.7 mg), $39(1.6 \mathrm{mg}), 44(1.8 \mathrm{mg})$, and $57(5.0 \mathrm{mg})$, respectively. WF 5-5 was purified by reversed-phase HPLC with a Gemini $5 \mathrm{u}$ C18 column $(250 \times 4.6 \mathrm{~mm}, 5 \mu \mathrm{m})$ eluted with a $\mathrm{MeOH}^{-\mathrm{H}_{2} \mathrm{O}}$ mixture $(20: 80,0.6 \mathrm{~mL} / \mathrm{min})$ to afford $52(4.2 \mathrm{mg})$. WF 6 was subjected to Diaion HP-20 CC eluted with water and a step gradient of methanol (10:0 to 0:10) to afford six subfractions (WF 6-1-6-6). WF 6-2 and 6-6 were further purified by $\mathrm{SiO}_{2} \mathrm{CC}$ and pTLC to obtain 5 (4.0 mg), 12 (2.6 mg), 49 (3.3 mg), 15 (3.5 $\mathrm{mg})$, and $58(0.4 \mathrm{~g})$. WF 7 was purified by Diaion HP-20 CC eluted with water and a step gradient of methanol (10:0 to 0:10) to obtain seven subfractions (WF 7-1-7-7). WF 7-6 was separated by repeated 
Sephadex LH-20 CC eluted with a step gradient mixture of water and methanol (10:0 to 0:10) to yield 1 (2.8 mg), 9 (17.0 mg), 11 (5.2 mg), 47 (2.6 g), 59 (1.5 g), and 60 (0.5 g). WF 8 was purified by $\mathrm{SiO}_{2} \mathrm{CC}$ eluted by chloroform and a step gradient with methanol and water (100:1:0.1 to 1:1:0.1) to obtain seven subfractions (WF 8-1-8-7). WF 8-4 was isolated by $\mathrm{SiO}_{2} \mathrm{CC}$ and pTLC to give 45 (2.7 mg), 13 (1.1 mg), and $72(1.9 \mathrm{mg})$. WF 10 was subjected to Sephadex LH-20 CC eluted with water and a step gradient of methanol (10:0 to 0:10) to obtain ten subfractions (WF 10-1-10-10). WF 10-3, 10-6, and 10-9 were further purified by pTLC to yield $42(0.8 \mathrm{mg}) ; 31(4.2 \mathrm{mg}), 46(12.3 \mathrm{mg})$, and $50(11.0 \mathrm{mg})$, and $51(1.3 \mathrm{mg})$ and 53 (2.2 mg), respectively. WF 12 was subjected to Diaion HP-20 CC eluted with a mixture of water and methanol (step gradient from 10:0 to 0:10) to afford seven subfractions (WF 12-1-12-7). WF 12-3 was purified by Sephadex LH-20 CC and further resolved on pTLC to produce 30 (1.9 mg), 34 (2.1 mg), and 73 (1.4 mg). WF 12-6 was isolated by repeated $\mathrm{SiO}_{2} \mathrm{CC}$ yield 2 (4.2 mg). WF 13 was resolved on a Sephadex LH-20 column eluted with water and methanol (step gradient from 10:0 to 0:10) to produce eight subfractions (WF 13-1-13-8). WF 13-3 was separated by $\mathrm{SiO}_{2} \mathrm{CC}$ and pTLC to obtain 32 (1.6 mg) and 33 (40.0 mg). WF 13-7 was resolved on Sephadex LH-20 CC and the minor fraction was isolated by repeated $\mathrm{SiO}_{2} \mathrm{CC}$ to result in $3(6.3 \mathrm{mg}), 27(33.0 \mathrm{mg})$, and $28(43.3 \mathrm{mg})$. WF 14 was subjected to $\mathrm{SiO}_{2}$ CC eluted with ethyl acetate and methanol (step gradient from 300:1 to 1:1) to give nine subfractions (WF 14-1-14-9). Compound 29 (7.5 mg) was obtained from the WF 14-7 by repeated $\mathrm{SiO}_{2} \mathrm{CC}_{\text {followed }}$ by recrystallization.

\subsubsection{Viglutin (1)}

Colorless powder; $[\alpha]_{\mathrm{D}}^{25}+36.9\left(c\right.$ 0.1, MeOH); IR (neat) $v_{\max }: 3416,2928,1647,1580,1383,1045$ $\mathrm{cm}^{-1}$; ESI-MS (rel. int. \%) $m / z 227\left([\mathrm{M}+\mathrm{H}]^{+}, 100\right), 209(43) ; \mathrm{HR}-\mathrm{ESI}-\mathrm{MS} m / z 249.1460\left([\mathrm{M}+\mathrm{Na}]^{+}\right)$ (Calcd for $\left.\mathrm{C}_{13} \mathrm{H}_{22} \mathrm{NaO}_{3}: 249.1467\right) ;{ }^{1} \mathrm{H}-\mathrm{NMR}\left(\mathrm{CD}_{3} \mathrm{OD}, 500 \mathrm{MHz}\right) \delta 5.78(1 \mathrm{H}, \mathrm{dq}, J=15.5,6.5 \mathrm{~Hz}, \mathrm{H}-9)$, $5.67(1 \mathrm{H}, \mathrm{ddd}, J=15.5,8.5,1.5 \mathrm{~Hz}, \mathrm{H}-8), 4.18(1 \mathrm{H}, \mathrm{d}, J=8.5 \mathrm{~Hz}, \mathrm{H}-7), 3.81(1 \mathrm{H}, \mathrm{m}, \mathrm{H}-13 \mathrm{~b}), 3.80(1 \mathrm{H}$, dddd, $J=12.0,7.5,5.0,3.5 \mathrm{~Hz}, \mathrm{H}-3), 3.61(1 \mathrm{H}, \mathrm{dd}, J=11.0,7.0 \mathrm{~Hz}, \mathrm{H}-13 \mathrm{a}), 2.44(1 \mathrm{H}, \mathrm{m}, \mathrm{H}-5), 1.73(1 \mathrm{H}$, m, H-4b), $1.73\left(3 \mathrm{H}, \mathrm{dd}, J=6.5,1.5 \mathrm{~Hz}, \mathrm{CH}_{3}-10\right), 1.51(1 \mathrm{H}, \mathrm{ddd}, J=12.0,12.0,11.5 \mathrm{~Hz}, \mathrm{H}-4 \mathrm{a}), 1.36(1 \mathrm{H}$, ddd, $J=12.6,5.0,1.5 \mathrm{~Hz}, \mathrm{H}-2 \mathrm{~b}), 1.31(1 \mathrm{H}, \mathrm{m}, \mathrm{H}-2 \mathrm{a}), 1.06\left(3 \mathrm{H}, \mathrm{s}, \mathrm{CH}_{3}-12\right), 0.96\left(3 \mathrm{H}, \mathrm{s}, \mathrm{CH}_{3}-11\right) ;{ }^{13} \mathrm{C}-\mathrm{NMR}$ $\left(\mathrm{CD}_{3} \mathrm{OD}, 125 \mathrm{MHz}\right) \delta 132.1$ (C-9), 129.6 (C-8), 84.4 (C-7), 81.2 (C-6), 69.7 (C-13), 68.5 (C-3), 46.8 (C-2), 43.7 (C-5), 37.7 (C-1), $31.6(\mathrm{C}-4), 25.9$ (C-11), 24.0 (C-12), 18.2 (C-10).

\subsubsection{Viglutoside (2)}

Yellowish amorphous powder; $[\alpha]_{\mathrm{D}}^{25}-23.6$ (c 0.3, MeOH); UV (MeOH) $\lambda_{\max }(\log \varepsilon): 221(3.78)$, 274 (3.38) nm; IR (neat) $v_{\max }: 3430,2924,1637 \mathrm{~cm}^{-1}$; ESI-MS (rel. int. \%) $\mathrm{m} / z 272\left([\mathrm{M}+\mathrm{H}]^{+}, 100\right)$; HR-ESI-MS $m / z 294.0952\left([\mathrm{M}+\mathrm{Na}]^{+}\right)\left(\right.$Calcd for $\left.\mathrm{C}_{12} \mathrm{H}_{17} \mathrm{NNaO}_{6}: 294.0954\right) ;{ }^{1} \mathrm{H}-\mathrm{NMR}(\mathrm{CD} \mathrm{OD}, 500$ $\mathrm{MHz}) \delta 8.03(1 \mathrm{H}, \mathrm{d}, J=2.5 \mathrm{~Hz}, \mathrm{H}-2), 7.32(1 \mathrm{H}, \mathrm{d}, J=8.5 \mathrm{~Hz}, \mathrm{H}-5), 7.21(1 \mathrm{H}, \mathrm{dd}, J=8.5,2.5 \mathrm{~Hz}, \mathrm{H}-4), 4.78$ $\left(1 \mathrm{H}, \mathrm{d}, J=2.0 \mathrm{~Hz}, \mathrm{H}-1^{\prime}\right), 4.65(1 \mathrm{H}, \mathrm{d}, J=12.0 \mathrm{~Hz}, \mathrm{H}-7 \mathrm{~b}), 4.51(1 \mathrm{H}, \mathrm{d}, J=12.0 \mathrm{~Hz}, \mathrm{H}-7 \mathrm{a}), 3.85(1 \mathrm{H}, \mathrm{dd}, J=$ 3.5, $\left.2.0 \mathrm{~Hz}, \mathrm{H}-2^{\prime}\right), 3.67\left(1 \mathrm{H}, \mathrm{dd}, J=9.5,3.5 \mathrm{~Hz}, \mathrm{H}-3^{\prime}\right), 3.60\left(1 \mathrm{H}, \mathrm{dd}, J=9.5,6.0 \mathrm{~Hz}, \mathrm{H}-5^{\prime}\right), 3.38(1 \mathrm{H}, \mathrm{dd}, J=$ 9.5, 9.5 Hz, H-4'), $1.25\left(1 \mathrm{H}, \mathrm{d}, J=6.0 \mathrm{~Hz}, \mathrm{H}-6^{\prime}\right) ;{ }^{13} \mathrm{C}-\mathrm{NMR}\left(\mathrm{CD}_{3} \mathrm{OD}, 125 \mathrm{MHz}\right) \delta 155.9(\mathrm{C}-3), 148.6(\mathrm{C}-6)$, 138.1 (C-2), 125.0 (C-4), 124.8 (C-5), $101.4\left(\mathrm{C}-1^{\prime}\right), 74.0\left(\mathrm{C}-4^{\prime}\right), 72.4\left(\mathrm{C}-3^{\prime}\right), 72.3\left(\mathrm{C}-2^{\prime}\right), 70.3(\mathrm{C}-7), 70.1\left(\mathrm{C}-5^{\prime}\right)$, $18.0\left(\mathrm{C}-6^{\prime}\right)$.

\subsubsection{Viglutanone (3)}

Colorless syrup; UV (MeOH) $\lambda_{\max }(\log \varepsilon): 299$ (3.44) nm; IR (neat) $v_{\max }: 3493,2953,2133,1703$, 1631, 1387, $1054 \mathrm{~cm}^{-1}$; ESI-MS (rel. int. \%) $\mathrm{m} / z 197$ ([M-H] $^{-}$, 100); HR-ESI-MS $m / z 197.0449$ ([M $\left.\mathrm{H}^{-}\right)\left(\right.$Calcd for $\mathrm{C}_{9} \mathrm{H}_{9} \mathrm{O}_{5}:$ 197.0450); ${ }^{1} \mathrm{H}-\mathrm{NMR}\left(\mathrm{CD}_{3} \mathrm{OD}, 400 \mathrm{MHz}\right) \delta 6.97(1 \mathrm{H}, \mathrm{s}, \mathrm{H}-5), 6.25(1 \mathrm{H}, \mathrm{s}, \mathrm{H}-3)$, $3.60(1 \mathrm{H}, \mathrm{t}, J=6.4 \mathrm{~Hz}, \mathrm{H}-9), 2.60(1 \mathrm{H}, \mathrm{t}, J=8.0 \mathrm{~Hz}, \mathrm{H}-7), 1.84(1 \mathrm{H}, \mathrm{tt}, J=8.0,6.4 \mathrm{~Hz}, \mathrm{H}-8) ;{ }^{13} \mathrm{C}-\mathrm{NMR}$ $\left(\mathrm{CD}_{3} \mathrm{OD}, 100 \mathrm{MHz}\right) \delta 165.8$ (C-10), 164.8 (C-2), 162.3 (C-4), 156.4 (C-6), 114.8 (C-3), 110.4 (C-5), 61.7 (C-9), $32.6(\mathrm{C}-7), 32.1$ (C-8). 


\subsubsection{Sodium Phaseate (4)}

Colorless powder; $[\alpha]_{\mathrm{D}}^{25}-9.1(c 0.5, \mathrm{MeOH}) ; \mathrm{UV}(\mathrm{MeOH}) \lambda_{\max }(\log \varepsilon): 249$ (3.55) nm; IR (neat) $v_{\max }: 3424,2937,1713,1644,1636,1550,1401,1334,1254 \mathrm{~cm}^{-1}$; HR-ESI-MS $\mathrm{m} / z 279.1234\left([\mathrm{M}-\mathrm{Na}]^{-}\right)$ (Calcd for $\left.\mathrm{C}_{15} \mathrm{H}_{19} \mathrm{O}_{5}: 279.1233\right) ;{ }^{1} \mathrm{H}-\mathrm{NMR}\left(\mathrm{CD}_{3} \mathrm{OD}, 400 \mathrm{MHz}\right) \delta 7.87(1 \mathrm{H}, \mathrm{d}, J=16.0 \mathrm{~Hz}, \mathrm{H}-8), 6.20(1 \mathrm{H}$, $\mathrm{d}, J=16.0 \mathrm{~Hz}, \mathrm{H}-7), 5.86(1 \mathrm{H}, \mathrm{br} \mathrm{s}, \mathrm{H}-10), 3.93(1 \mathrm{H}, \mathrm{dd}, J=7.2,2.8 \mathrm{~Hz}, \mathrm{H}-12 \mathrm{~b}), 3.65(1 \mathrm{H}, \mathrm{d}, J=7.2 \mathrm{~Hz}$, H-12a), $2.81(1 \mathrm{H}, \mathrm{d}, J=18.0 \mathrm{~Hz}, \mathrm{H}-4 \mathrm{~b}), 2.71(1 \mathrm{H}, \mathrm{dd}, J=18.0,2.4 \mathrm{~Hz}, \mathrm{H}-2 \mathrm{~b}), 2.45(1 \mathrm{H}, \mathrm{dd}, J=18.0,2.4$ Hz, H-4a), 2.37 (1H, dd, J = 18.0, $2.4 \mathrm{~Hz}, \mathrm{H}-2 \mathrm{a}), 1.95\left(3 \mathrm{H}, \mathrm{s}, \mathrm{CH}_{3}-15\right), 1.22\left(3 \mathrm{H}, \mathrm{s}, \mathrm{CH}_{3}-14\right), 1.00(3 \mathrm{H}, \mathrm{s}$, $\left.\mathrm{CH}_{3}-13\right) ;{ }^{13} \mathrm{C}-\mathrm{NMR}\left(\mathrm{CD}_{3} \mathrm{OD}, 100 \mathrm{MHz}\right) \delta 211.3$ (C-3), 175.0 (C-11), 141.6 (C-9), 134.1 (C-8), 129.2 (C-7), 127.9 (C-10), 87.8 (C-5), 82.8 (C-6), 78.5 (C-12), 54.0 (C-4), 53.2 (C-2), 49.0 (overlapped by MeOH, C-1), 20.5 (C-15), 19.4 (C-14), 15.8 (C-13).

\subsubsection{Sodium $p$-Coumarate (5)}

Colorless powder; UV (MeOH) $\lambda_{\max }(\log \varepsilon): 282$ (3.83) nm; IR (neat) $v_{\max }: 3403,2941,1550,1414$, 1389, 1250, $1085 \mathrm{~cm}^{-1}$; ESI-MS (rel. int. \%) m/z 163 ([M-Na]', 100); HR-ESI-MS m/z 163.0396 ([M $\left.\mathrm{Na}]^{-}\right)\left(\right.$Calcd for $\mathrm{C}_{9} \mathrm{H}_{7} \mathrm{O}_{3}:$ 163.0395); ${ }^{1} \mathrm{H}-\mathrm{NMR}\left(\mathrm{CD}_{3} \mathrm{OD}, 400 \mathrm{MHz}\right) \delta 7.36(2 \mathrm{H}, \mathrm{d}, J=8.8 \mathrm{~Hz}, \mathrm{H}-2,6)$, $7.33(1 \mathrm{H}, \mathrm{d}, J=15.6 \mathrm{~Hz}, \mathrm{H}-7), 6.75(2 \mathrm{H}, \mathrm{d}, J=8.8 \mathrm{~Hz}, \mathrm{H}-3,5), 6.33(1 \mathrm{H}, \mathrm{d}, J=15.6 \mathrm{~Hz}, \mathrm{H}-8) ;{ }^{13} \mathrm{C}-\mathrm{NMR}$ $\left(\mathrm{CD}_{3} \mathrm{OD}, 100 \mathrm{MHz}\right) \delta 176.4$ (C-9), 160.0 (C-4), 141.0 (C-7), 130.1 (C-2 and -6), 128.6 (C-1), 123.2 (C-8), 116.6 (C-3 and -5).

\subsection{Anti-Inflammatory Bioactivity Examination}

The assays of the generation of superoxide anion and elastase release inhibition examinations were determined as described previously [43]. The experimental details were provided in the Supplementary Materials.

Supplementary Materials: The following are available online, S1: Complete extraction and isolation procedures; S2: References of the known compounds; S3: Anti-inflammatory bioactivity experimental procedures; Table S1: Inhibitory effects of isolated compounds; Figures S1-37: NMR spectra of compounds 1-5.

Author Contributions: Conceptualization, P.-C.K. and J.T.C.T.; Data Curation and Investigation, S.-H.L., Y.-C.L., and M.-L.Y.; Methodology, T.-L.H. and C.-C.W.; Resources, M.-L.Y. and P.-C.K.; Writing-Original Draft, Y.-C.L.; Writing-Review \& Editing, S.-H.L., P.-C.K., and J.T.C.T. All authors read and approved the final manuscript.

Funding: This research is sponsored by the Ministry of Science and Technology (MOST), Taiwan, granted to P.-C.K. and J.T.C.T. The authors are also thankful for partial financial support from Chang Gung Memorial Hospital (CMRPF1G0241 3, CMRPF1F0061 3, and BMRP450 granted to T.-L.H.).

Conflicts of Interest: The authors declare no conflict of interest.

\section{References}

1. Na, H.K.; Kim, E.H.; Jung, J.H.; Lee, H.H.; Hyun, J.W.; Surh, Y.J. (-)-Epigallocatechin gallate induces Nrf 2-mediated antioxidant enzyme expression via activation of PI3K and ERK in human mammary epithelial cells. Arch. Biochem. Biophys. 2008, 476, 171-177. [CrossRef]

2. Swami, S.; Krishnan, A.V.; Moreno, J.; Bhattacharyya, R.S.; Gardner, C.; Brooks, J.D.; Peehl, D.M.; Feldman, D. Inhibition of prostaglandin synthesis and actions by genistein in human prostate cancer cells and by soy isoflavones in prostate cancer patients. Int. J. Cancer 2009, 124, 2050-2059. [CrossRef] [PubMed]

3. Bar-Sela, G.; Epelbaum, R.; Schaffer, M. Curcumin as an anti-cancer agent: Review of the gap between basic and clinical applications. Curr. Med. Chem. 2010, 17, 190-197. [CrossRef] [PubMed]

4. Kuo, P.C.; Yang, C.J.; Lee, Y.C.; Chen, P.C.; Liu, Y.C.; Wu, S.N. The comprehensive electrophysiological study of curcuminoids on delayed-rectifier $\mathrm{K}^{+}$currents in insulin-secreting cells. Eur. J. Pharmacol. 2018, 819, 233-247. [CrossRef]

5. Shu, L.; Cheung, K.L.; Khor, T.O.; Chen, C.; Kong, A.N. Phytochemicals: Cancer chemoprevention and suppression of tumor onset and metastasis. Cancer Metastasis Rev. 2010, 29, 483-502. [CrossRef] [PubMed] 
6. Johnson, S.M.; Wang, X.; Evers, B.M. Triptolide inhibits proliferation and migration of colon cancer cells by inhibition of cell cycle regulators and cytokine receptors. J. Surg. Res. 2011, 168, 197-205. [CrossRef] [PubMed]

7. Newman, D.J.; Cragg, G.M.; Snader, K.M. The influence of natural products upon drug discovery. Nat. Prod. Rep. 2000, 17, 215-234. [CrossRef] [PubMed]

8. Boudjou, S.; Oomah, B.D.; Zaidi, F.; Hosseinian, F. Phenolics content and antioxidant and anti-inflammatory activities of legume fractions. Food Chem. 2013, 138, 1543-1550. [CrossRef]

9. Lima, A.I.; Mota, J.; Monteiro, S.A.; Ferreira, R.M. Legume seeds and colorectal cancer revisited: Protease inhibitors reduce MMP-9 activity and colon cancer cell migration. Food Chem. 2016, 197, 30-38. [CrossRef]

10. Hu, X.R.; Chou, G.X.; Zhang, C.G. Flavonoids, alkaloids from the seeds of Crotalaria pallida and their cytotoxicity and anti-inflammatory activities. Phytochemistry 2017, 143, 64-71. [CrossRef] [PubMed]

11. Malech, H.L.; Gallin, J.I. Neutrophils in human diseases. N. Engl. J. Med. 1987, 317, 687-694. [CrossRef] [PubMed]

12. Witko-Sarsat, V.; Rieu, P.; Descamps-Latscha, B.; Lesavre, P.; Halbwachs-Mecarelli, L. Neutrophils: Molecules, functions and pathophysiological aspects. Lab. Investig. 2000, 80, 617-653. [CrossRef]

13. Okajima, K.; Harada, N.; Uchiba, M. Ranitidine reduces ischemia/reperfusion-induced liver injury in rats by inhibiting neutrophil activation. J. Pharmacol. Exp. Ther. 2002, 301, 1157-1165. [CrossRef]

14. Ennis, M. Neutrophils in asthma pathophysiology. Curr. Allergy Asthma Rep. 2003, 3, 159-165. [CrossRef]

15. Vinten-Johansen, J. Involvement of neutrophils in the pathogenesis of lethal myocardial reperfusion injury. Cardiovasc. Res. 2004, 61, 481-497. [CrossRef] [PubMed]

16. Hwang, T.L.; Li, G.L.; Lan, Y.H.; Chia, Y.C.; Hsieh, P.W.; Wu, Y.H.; Wu, Y.C. Potent inhibition of superoxide anion production in activated human neutrophils by isopedicin, a bioactive component of the Chinese medicinal herb Fissistigma Oldhamii. Free Radic. Biol. Med. 2009, 46, 520-528. [CrossRef] [PubMed]

17. Huang, T.C.; Ohashi, H. Flora of Taiwan, 2nd ed.; Editorial Committee of Flora of Taiwan: Taipei, Taiwan, 1993; Volume 3, p. 385.

18. Sreerama, Y.N.; Sashikala, V.B.; Pratape, V.M. Phenolic compounds in cowpea and horse gram flours in comparison to chickpea flour: Evaluation of their antioxidant and enzyme inhibitory properties associated with hyperglycemia and hypertension. Food Chem. 2012, 133, 156-162. [CrossRef]

19. Silva, L.R.; Pereira, M.J.; Azevedo, J.; Gonçalves, R.F.; Valentão, P.; de Pinho, P.G.; Andrade, P.B. Glycine $\max ($ L.) Merr., Vigna radiata L. and Medicago sativa L. sprouts: A natural source of bioactive compounds. Food Res. Int. 2013, 50, 167-175. [CrossRef]

20. Seneviratne, G.I.; Harborne, J.B. Constitutive flavonoids and induced isoflavonoids as taxonomic makers in the genus Vigna. Biochem. Syst. Ecol. 1992, 20, 459-467. [CrossRef]

21. Soucek, J.; Skvor, J.; Pouckova, P.; Matousek, J.; Slavik, T.; Matousek, J. Mung bean (Phaseolus aureus) nuclease and its biological and antitumor effects. Neoplasma 2006, 53, 402-409.

22. Joanitti, G.A.; Azevedo, R.B.; Freitas, S.M. Apoptosis and lysosome membrane permeabilization induction on breast cancer cells by an anticarcinogenic Bowman-Birk protease inhibitor from Vigna unguiculata seeds. Cancer Lett. 2010, 293, 73-81. [CrossRef]

23. Lattanzio, V.; Arpaia, S.; Cardinali, A.; Venere, D.D.; Linsalata, V. Role of endogenous flavonoids in resistance mechanism of Vigna to aphids. J. Agric. Food Chem. 2000, 48, 5316-5320. [CrossRef]

24. Franco, O.L.; dos Santos, R.C.; Batista, J.A.N.; Mendes, A.C.M.; de Araújo, M.A.M.; Monnerat, R.G.; Grossi-de-Sá, M.F.; de Freitas, S.M. Effects of black-eyed pea trypsin/chemotrypsin inhibitor on proteolytic activity and on development of Anthonomus grandis. Phytochemistry 2003, 63, 343-349. [CrossRef]

25. Yao, Y.; Cheng, X.Z.; Wang, L.X.; Wang, S.H.; Ren, G. Major phenolic compounds, antioxidant capacity and antidiabetic potential of rice bean (Vigna umbellata L.) in China. Int. J. Mol. Sci. 2012, 13, 2707. [CrossRef]

26. Yao, Y.; Cheng, X.; Wang, S.; Wang, L.; Ren, G. Influence of altitudinal variation on the antioxidant and antidiabetic potential of adzuki bean (Vigna angularis). Int. J. Food Sci. Nutr. 2012, 63, 117-124. [CrossRef]

27. Han, K.H.; Fukushima, M.; Ohba, K.; Shimada, K.I.; Sekikawa, M.; Chiji, H.; Lee, C.H.; Nakano, M. Hepatoprotective effects of the water extract from adzuki bean hulls on acetaminophen-induced damage in rat liver. J. Nutr. Sci. Vitaminol. 2004, 50, 380-383. [CrossRef]

28. Kojima, M.; Yamashita, S.; Nishi, S.; Saito, Y.; Maeda, R. Antioxidative effect and liver protective action of adzuki polyphenol. Nippon Shokuhin Kagaku Kogaku Kaishi 2006, 53, 386-392. [CrossRef] 
29. Sato, S.; Mukai, Y.; Yamate, J.; Kato, J.; Kurasaki, M.; Hatai, A.; Sagai, M. Effect of polyphenol-containing adzuki bean (Vigna angularis) extract on blood pressure elevation and macrophage infiltration in the heart and kidney of spontaneously hypertensive rats. Clin. Exp. Pharmacol. Physiol. 2008, 35, 43-49. [CrossRef]

30. Sato, S.; Mukai, Y.; Yamate, J. Beneficial effects of adzuki bean (Vigna angularis) extract: Anti-oxidant, anti-hypertension and treatment for renal damage. Curr. Nutr. Food Sci. 2009, 5, 217-222. [CrossRef]

31. Franco, O.L.; Murad, A.M.; Leite, J.R.; Mendes, P.A.M.; Prates, M.V.; Jr, C.B. Identification of a cowpea $\gamma$-thionin with bactericidal activity. FEBS J. 2006, 273, 3489-3497. [CrossRef]

32. Thembo, K.M.; Vismer, H.F.; Nyazema, N.Z.; Gelderblom, W.C.A.; Katerere, D.R. Antifungal activity of four weedy plant extracts against selected mycotoxigenic fungi. J. Appl. Microbiol. 2010, 109, 1479-1486. [CrossRef]

33. Mukai, Y.; Sato, S. Polyphenol-containing adzuki bean (Vigna angularis) extract attenuates blood pressure elevation and modulates nitric oxide synthase and caveolin-1 expressions in rats with hypertension. Nutr. Metab. Cardiovasc. Dis. 2009, 19, 491-497. [CrossRef]

34. Mukai, Y.; Sato, S. Polyphenol-containing adzuki bean (Vigna angularis) seed coats attenuate vascular oxidative stress and inflammation in spontaneously hypertensive rats. J. Nutr. Biochem. 2011, 22, 16-21. [CrossRef]

35. Itoh, T.; Furuichi, Y. Lowering serum cholesterol level by feeding a 40\% ethanol-eluted fraction from HP-20 resin treated with hot water extract of adzuki beans (Vigna angularis) to rats fed a high-fat cholesterol diet. Nutrition 2009, 25, 318-321. [CrossRef]

36. Solanki, Y.B.; Jain, S.M. Antihyperlipidemic activity of Clitoria ternatea and Vigna mungo in rats. Pharm. Biol. 2010, 48, 915-923. [CrossRef]

37. Leu, Y.L.; Hwang, T.L.; Kuo, P.C.; Liou, K.P.; Huang, B.S.; Chen, G.F. Constituents from Vigna vexillata and their anti-inflammatory activity. Int. J. Mol. Sci. 2012, 13, 9754-9768. [CrossRef]

38. Miyake, Y.; Ebata, M. The structures of a $\beta$-galactosidase inhibitor, galactostatin, and its derivatives. Agric. Biol Chem. 1988, 52, 661-666.

39. Kashman, Y.; Yosief, T.; Carmeli, S. New triterpenoids from the Red Sea sponge Siphonochalina siphonella. J. Nat. Prod. 2001, 64, 175-180. [CrossRef]

40. Arai, S.; Todoroki, Y.; Ibaraki, S.; Naoe, Y.; Hirai, N.; Ohigashi, H. Synthesis and biological activity of $3^{\prime}$-chloro, -bromo, and-iodoabscisic acids, and biological activity of $3^{\prime}$-fluoro-8'-hydroxyabscisic acid. Phytochemistry 1999, 52, 1185-1193. [CrossRef]

41. Liao, C.R.; Kuo, Y.H.; Ho, Y.L.; Wang, C.Y.; Yang, C.S.; Lin, C.W.; Chang, Y.S. Studies on cytotoxic constituents from the leaves of Elaeagnus oldhamii Maxim. in non-small cell lung cancer A549 cells. Molecules 2014, 19, 9515-9534. [CrossRef]

42. Swisłocka, R.; Kowczyk-Sadowy, M.; Kalinowska, M.; Lewandowski, W. Spectroscopic (FT-IR, FT-Raman, ${ }^{1} \mathrm{H}$ and $\left.{ }^{13} \mathrm{C} \mathrm{NMR}\right)$ and theoretical studies of $p$-coumaric acid and alkali metal $p$-coumarates. Spectroscopy 2012, 27, 35-48. [CrossRef]

43. Yu, H.P.; Hsieh, P.W.; Chang, Y.J.; Chung, P.J.; Kuo, L.M.; Hwang, T.L. 2-(2-Fluorobenzamido)benzoate ethyl ester (EFB-1) inhibits superoxide production by human neutrophils and attenuates hemorrhagic shock-induced organ dysfunction in rats. Free Radic. Biol. Med. 2011, 50, 1737-1748. [CrossRef]

Sample Availability: Samples of all the isolated compounds are available from the authors. 